\title{
Harnessing Electrical Power from Hybrid Biomass- Solid Waste Energy Resources for Microgrids in Underdeveloped and Developing Countries
}

\author{
Muhammad Amir Raza \\ Department of Electrical Engineering \\ NED University of Engineering and Technology \\ Karachi, Pakistan \\ amir.eed.neduet@gmail.com \\ Khalid Rafique \\ Azad Jammu and Kashmir Information \\ Technology Board \\ Muzaffarabad, Pakistan \\ khalidrafiquepk@gmail.com
}

\author{
Krishan Lal Khatri \\ Department of Electrical Engineering \\ NED University of Engineering and Technology \\ Karachi, Pakistan \\ engrkrishan@yahoo.com
}

\author{
Abdul Sattar Saand \\ Electrical Engineering Department \\ Quaid-e-Awam University of Engineering, Science and \\ Technology, Nawabshah, Pakistan \\ as-saand@quest.edu.pk
}

\begin{abstract}
This paper presents an energy plan for harnessing electrical power from hybrid energy resources, including biomass and solid waste, through hybrid technologies for microgrid development to overcome the current energy crisis and provide future sustainable electricity pathways for a developing country. Biomass and solid waste were collected from different dumping sites in Pakistan and were tested for their calorific value, which was found to be $6519 \mathrm{Kcal} / \mathrm{Kg}$. The total power was calculated based on this calorific value and it was found that there is a potential of total 11,989.5GW of power generation. Thus, hybrid energy resources are suitable for harnessing electrical energy through hybrid technologies. Different hybrid systems were examined for these resources and the gasification technique is finally proposed as the most suitable method for producing energy from biomass and solid waste resources in Pakistan. This technique is also found to be economically feasible for processing all kinds of waste.
\end{abstract}

Keywords-biomass; solid waste; electrical power; sustainable development; developing countries; underdeveloped countries

\section{INTRODUCTION}

A developing country may face an exponential growth of population and industrialization, which is resulting in huge requirements of energy. This further leads to the exploitation of fossil fuels, such as domestic coal, natural gas, and oil which are not renewable. The use of fossil fuels poses a threat to the environment and public health in terms of harmful Greenhouse Gases (GHG) and huge production of waste [1]. The generated Municipal Solid Waste (MSW) will globally reach 2200 million tons annually by 2025 which would increase to 2600 million tons by $2030[2,3]$. Sewage sludge produced from industrial and household wastewater treatment produces thousands of tons of solid waste daily [4]. Proper treatment of biomass and solid waste is an alternative option for power generation which reduces ecological and social issues [5]. Facilitating biomass and solid waste renewable resources for power generation instead of fossil fuels provides better technoeconomic opportunities for Pakistan [5]. If biomass and solid waste resources are exploited, the ratio of renewable power generation would be increased from $2 \%$ to $27 \%$ and would cater for the $56 \%$ of local energy needs [6]. The major advantage of biomass and solid waste is that they can be available at any location in contradiction with fossil fuels[6].

There are many biomass and solid waste resources including human waste, MSW, food waste, firewood, shrubbery waste, fabrics, paper products, latex, and plastics [7]. The quantity and composition of biomass and solid waste vary greatly depending upon the region and human living standards [7]. There are four major sectors involved in the production of biomass and solid waste in Pakistan: agriculture, domestic, industrial, and commercial. Easy accessibility to biomass and solid waste resources provides a sustainable option for harnessing electrical power while resolving the issue of inappropriate dumping of biomass and solid waste. Biomass and solid waste are considered as the most feasible option for biofuel production and biochemical energy generation [8]. Biomass and solid waste are converted into biofuel through thermochemical conversion processes including combustion, gasification, incineration, and pyrolysis [9]. Gasification is a suitable option for managing large quantities of biomass and solid waste in Pakistan because it produces multiple outputs including heat for commercial purposes, energy for residential purposes, and bio-oils for the chemical industries while it utilizes all types of biomass and solid waste products [10]. The 
incineration techniques, amongst all considered techniques, are responsible for large environmental pollution [10].

Economic activities in the developing countries lead to augmented generation of biomass and solid waste. These sources could be used for the generation of electrical energy, bio-oil, and biofuel [11]. The usage of biomass and solid waste is valuable because these sources are available in huge quantities [11]. The type of material and the quantity of generated waste are different in each region as shown in Table I. Pakistan generates over 64,000tons/day of biomass and solid waste. This material is useful for power generation because it has good calorific value $(6.9 \mathrm{~J} / \mathrm{kg})$ [12]. In the main municipalities, the total production capacity of solid waste is around 712 million tons/year [12]. However, in India, the intermediate and massive populated cities generate a large quantity of waste which is increasing at a rate of $6 \%$ every year [13]. The production of biomass at a global level is also high [13].

TABLE I. PRODUCTION CAPACITY OF BIOMASS AND SOLID WASTE IN VARIOUS COUNTRIES

\begin{tabular}{|c|c|c|c|}
\hline Ref & Country & Material type & Production capacity \\
\hline$[12]$ & \multirow{2}{*}{ Pakistan } & Biomass & 46886 million tons/year \\
\cline { 3 - 4 } & & Solid waste & 8536 million tons/year \\
\hline$[13]$ & \multirow{2}{*}{ India } & Biomass & 180 million tons/year \\
\cline { 3 - 4 } & & Solid waste & 600 million tons/year \\
\hline$[14]$ & Europe & Biomass & 205 million tons/year \\
\hline$[15]$ & China & Biomass & 850 million tons/year \\
\hline$[16]$ & Brazil & Biomass & 597 million tons/year \\
\hline
\end{tabular}

The utilization of biomass and solid waste for power generation in Pakistan is the focus of this study. However, to overcome the environmental pollution and available energy issue in the country, the research is on the way for converting unused sources into useful sources by using hybrid technologies for the generation of energy and heat. The main aim of the current research is to develop an energy plan for the energy sector of Pakistan in order to overcome the energy crisis and identify a future path of electricity supply for sustainable development. This research identifies the quantity and quality of solid waste and biomass resources and it justifies the suitability of harnessing electrical power from them. An experiment was performed in the lab for the final testing of waste pallets and the waste calorific value was identified in order to calculate its total power capacity. Furthermore, hybrid technologies were examined and the most suitable technology for hybrid resources was selected.

\section{MATERIALS AND METHODS}

\section{A. Study Area}

Pakistan is located in the north western part of South Asia and covers an area of $881,913 \mathrm{Km}^{2}$ with an overall population of 207 million with a growth rate of $2.4 \%$ [17]. Its neighboring countries are China from the northeastern side, India from the eastern side, Iran, and Afghanistan from the western side and the Arabian Sea from the southern side. The growth rate of the Gross Domestic Product (GDP) in Pakistan is 5.8\% [18] whereas the per capita income is $\$ 1641$ [18]. If the growth rate of the population continues to increase at a pace of $2.4 \%$ then by 2050 the country will become the $4^{\text {th }}$ largest in the world [18]. The power consumption per capita is around $500 \mathrm{kWh}$ which is quite low compared with the global per-capita of power consumption which is around 2603kWh [19].

\section{B. Compostion of Biomass and Solid Waste}

Table II shows the chemical composition criteria of biomass resources through ultimate and proximate analysis on the physicochemical characteristics [20]. These characteristics would help to identify the selectivity and suitability of biomass resources for power generation. The chemical composition of solid waste is quite different from the biomass in the sense that the quality and capacity of solid waste is affected by various factors including the living standards, weather conditions, surrounding region, and financial status. Solid waste normally comprises of organic waste, inorganic waste, hazardous waste, paper waste, plastic waste, and textile waste. The waste composition type and percentage is shown in Figure 1 [21]. The physicochemical characteristics of solid waste are obtained from ultimate and proximate analysis tests. The ultimate analysis test is used to find the proportion of oxygen, nitrogen, sulphur, carbon, and hydrogen in the total solid waste whereas the proximate analysis test is used to find the fixed carbon, ash, moistness, and volatile matter. The physiochemical characteristics of solid waste are shown in Figure 2 [21].

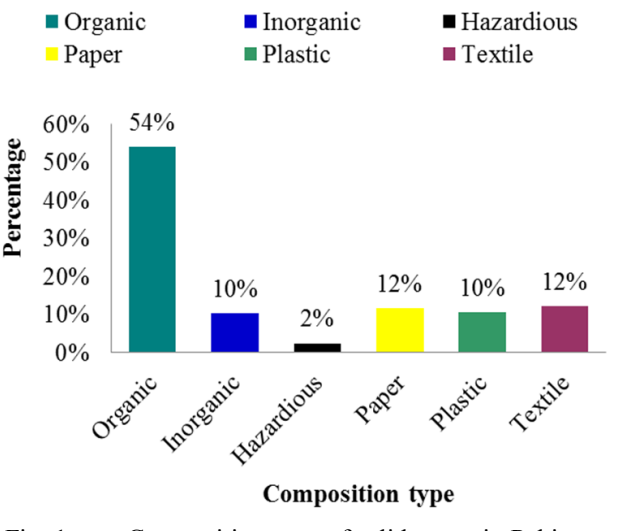

Fig. 1. Composition type of solid waste in Pakistan.

\section{Experimental Study of Biomass and Solid Waste Samples}

An experimental setup is designed based on the quartering method as shown in Figure 3. Initially, $25 \mathrm{~kg}$ of biomass and $25 \mathrm{~kg}$ of solid waste were collected from different regions of Pakistan. Then, manual mixing and cutting were performed and all the waste was gathered at a single place. Further, this total waste was divided into 8 sections namely I, II, III, IV, V, VI, VII, and VIII. These sections were separated into even (II, IV, VI, and VIII) and odd sections (I, III, V, and VII). Even sections were mixed and again separated into two sections namely $\mathrm{M}$ and N. Similarly, odd section were mixed and separated into two sections namely $\mathrm{O}$ and $\mathrm{P}$. Then these four sections ( $\mathrm{M}, \mathrm{N}, \mathrm{O}$ and $\mathrm{P}$ ) were mixed diagonally like $\mathrm{M} \& \mathrm{P}$ and $\mathrm{N} \& \mathrm{O}$ and separated into two sections like $\mathrm{M} \& \mathrm{P}$ into $\mathrm{Y}$ and $\mathrm{N} \& \mathrm{O}$ into $\mathrm{Z}$. Finally, $\mathrm{Y}$ and $\mathrm{Z}$ were mixed for the final sample of analysis. The manual mixing and cutting were performed many times until the weight became $15 \mathrm{~kg}$. 
TABLE II. BIOMASS CHEMICAL COMPOSITION [22, 23]

\begin{tabular}{|c|c|c|c|c|c|c|c|c|}
\hline & Sulphur & Carbon & Oxygen & Hydrogen & Fixed carbon & Ash & Volatile matter & Moisture \\
\hline Rice husk & 0.02 & 35.6 & 59.7 & 4.5 & 14.6 & 26.2 & 59.2 & 8.8 \\
\hline Bamboo & 0.09 & 50.52 & 42.80 & 6.04 & 16.05 & 1.95 & 83.95 & 6.14 \\
\hline Sugarcane bagasse & 0.09 & 46.6 & 43.3 & 5.92 & 8.30 & 3.90 & 82.5 & 5.25 \\
\hline Pine sawdust & 0.36 & 49.79 & 44.12 & 6.36 & 13.91 & 1.29 & 82.03 & 2.77 \\
\hline Oat & - & 42.3 & 40.9 & 6.3 & - & 1.5 & - & 7.1 \\
\hline
\end{tabular}

$\begin{array}{lll}\text { Volatile matter } & \text { Nitrogen } & \text { Carbon } \\ \text { Sulphur } & \text { Oxygen } & \text { Hydrogen }\end{array}$

Fixed carbon Ash
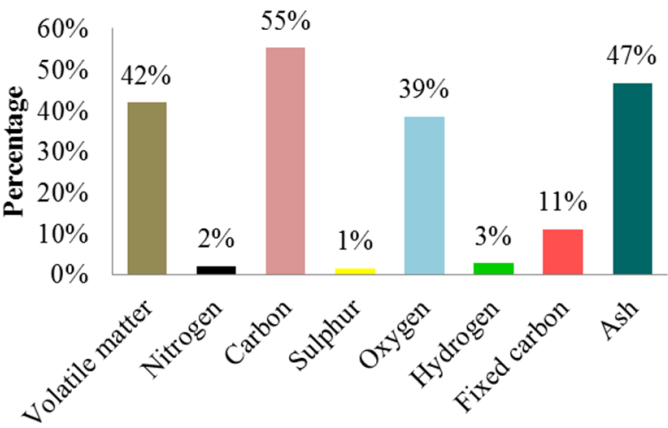

Composition content

Fig. 2. Composition content of solid waste in Pakistan.

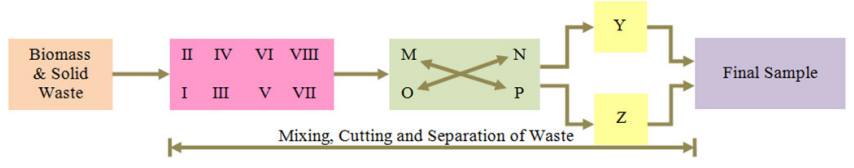

Fig. 3. Quartering diagram method for waste sampling.

\section{Determination of Heating or Calorific Value}

The calorific value is highly dependent on the amount of heat produced during the combustion process. The calorific value of the final sample of waste pellets was determined in the laboratory using the Gallen Kamp Ballistic Bomb (GKBB) Calorimeter. The net calorific value is determined as $6519 \mathrm{kcal} / \mathrm{kg}$. However, from other research data, the calorific value ranges from $9 \mathrm{MJ} / \mathrm{kg}$ to $44 \mathrm{MJ} / \mathrm{kg}$ respectively [24]. Equations (1) and (2) were used for finding the higher and lower values of calorific of mixed biomass and solid waste pallets [25].

$$
\begin{aligned}
& \text { Higher calorific value }=\frac{\sum \mathrm{Qp}(\mathrm{C} . \mathrm{V}) \mathrm{H}}{\mathrm{Tp}} \\
& \text { Lower calorific value }=\frac{\sum \mathrm{Qp}(\mathrm{C} . \mathrm{V}) \mathrm{L}}{\mathrm{Tp}}
\end{aligned}
$$

where $(\mathrm{C} . \mathrm{V}) \mathrm{L}$ is the lower calorific value in $\mathrm{kcal} / \mathrm{kg},(\mathrm{C} . \mathrm{V}) \mathrm{H}$ is the higher calorific value in $\mathrm{kcal} / \mathrm{kg}, \mathrm{Qp}$ is the quantity of the specific material in the total waste pallets in $\mathrm{kg}$, and $\mathrm{Tp}$ is the total waste pallets in $\mathrm{kg}$.

\section{E. Theoretical Power Potential of Biomass and Solid Waste}

The power potential of mixed biomass and solid waste pallets can be calculated by:

$$
\mathrm{Ep}=(\mathrm{C} . \mathrm{V}) \mathrm{L} \times \mathrm{Aw} \times 1.16
$$

where Ep is the energy potential in $\mathrm{kWh}$ and $\mathrm{Aw}$ is the aggregate waste in $\mathrm{kg}$.

\section{RESULTS AND DISCUSSION}

\section{A. Net Power Calculations}

Net power of biomass and solid waste pallets were calculated as follows:

The Heat Of Combustion (HOC) was calculated using the total Quantity of Waste Pallets (QWP) and Calorific Value $(\mathrm{CV})$ :

$$
\mathrm{HOC}=\mathrm{QWP} \times \mathrm{CV}
$$

$$
\mathrm{HOC}=55,422,000,000 \text { ton } \times 6,519,000 \mathrm{kcal} / \mathrm{ton}
$$

$$
\mathrm{HOC}=3.61296018 \times 10^{17} \mathrm{kcal}
$$

The Heat Output (HO), considering efficiency of 25\% [25], was:

$$
\begin{gathered}
\mathrm{HO}=\text { overall efficiency } \times \mathrm{HOC} \\
\mathrm{HO}=0.25 \times 3.61296018 \times 10^{17} \\
\mathrm{HO}=9.03240045 \times 10^{16} \mathrm{kcal}
\end{gathered}
$$

With $1 \mathrm{kWh}$ equal to $860 \mathrm{kcal}$ the Units Generated/Annum (UGA) are:

$$
\mathrm{UGA}=\mathrm{HO} / 860
$$

$$
\begin{aligned}
\text { UGA } & =9.03240045 \times 10^{16} / 860 \mathrm{kcal} \\
U G A & =105,027,912,209,302.3 \mathrm{kWh} \\
\mathrm{UGA} & =105,027,912,209.3023 \mathrm{MWh}
\end{aligned}
$$

The Average Load on the System (ALS) is:

$$
\mathrm{ALS}=\mathrm{UGA} / \text { total hours in a year }
$$

$$
\begin{gathered}
\mathrm{ALS}=105,027,912,209.3023 \mathrm{MWh} / 8760 \mathrm{~h} \\
\mathrm{ALS}=11,989,487.69512584 \mathrm{MW}
\end{gathered}
$$

This mathematical framework calculated the total power production capacity from the hybrid energy resources based on authentic and realistic data. The available capacity and quality of waste pallets can generate a power of $11,989.5 \mathrm{GW}$. This power capacity can drive the economy of the country at a great extent but there is a need to develop a proper energy harnessing system with sufficient financing and resources. 
TABLE III. TECHNOLOGY SELECTION PARAMETERS FOR POWER GENERATION

\begin{tabular}{|c|c|c|c|c|}
\hline Parameters & Pyrolysis & Plasma & Gasification & Incineration \\
\hline Feedstock & Solid waste & Solid waste & Biomass and solid waste & Biomass and solid waste \\
\hline Variable composition & $\begin{array}{l}\text { Did not accept } \\
\text { variable waste }\end{array}$ & $\begin{array}{c}\text { Did not accept variable } \\
\text { waste }\end{array}$ & $\begin{array}{l}\text { Accept heterogeneous } \\
\text { waste of all types }\end{array}$ & $\begin{array}{l}\text { Little difficult to proceed } \\
\text { variable waste }\end{array}$ \\
\hline Product & $\begin{array}{l}\text { Oil, Syngas and } \\
\text { energy }\end{array}$ & Syngas and energy & Syngas and energy & Heat and energy \\
\hline Operating cost & $150 \$$ per tone & $120 \$$ per tone & $60 \$$ per tone & $60 \$$ per tone \\
\hline Annual capital cost & $1500 \$$ per tone & $1300 \$$ per tone & $850 \$$ per tone & $775 \$$ per tone \\
\hline Disposal & $\begin{array}{l}\text { Ash } 0.3 \text { tone per } \\
\text { feedstock tone }\end{array}$ & Bottom ash around $10 \%$ & Less than $1 \%$ bottom ash & Around $5 \%$ bottom ash \\
\hline Energy production capability & $800 \mathrm{kWh}$ per tone & $600 \mathrm{kWh}$ per tone & $800 \mathrm{kWh}$ per tone & $850 \mathrm{Kwh}$ per tone \\
\hline Efficiency & Less than $18 \%$ & Less than $10 \%$ & $18 \%$ to $30 \%$ & $18 \%$ to $25 \%$ \\
\hline
\end{tabular}

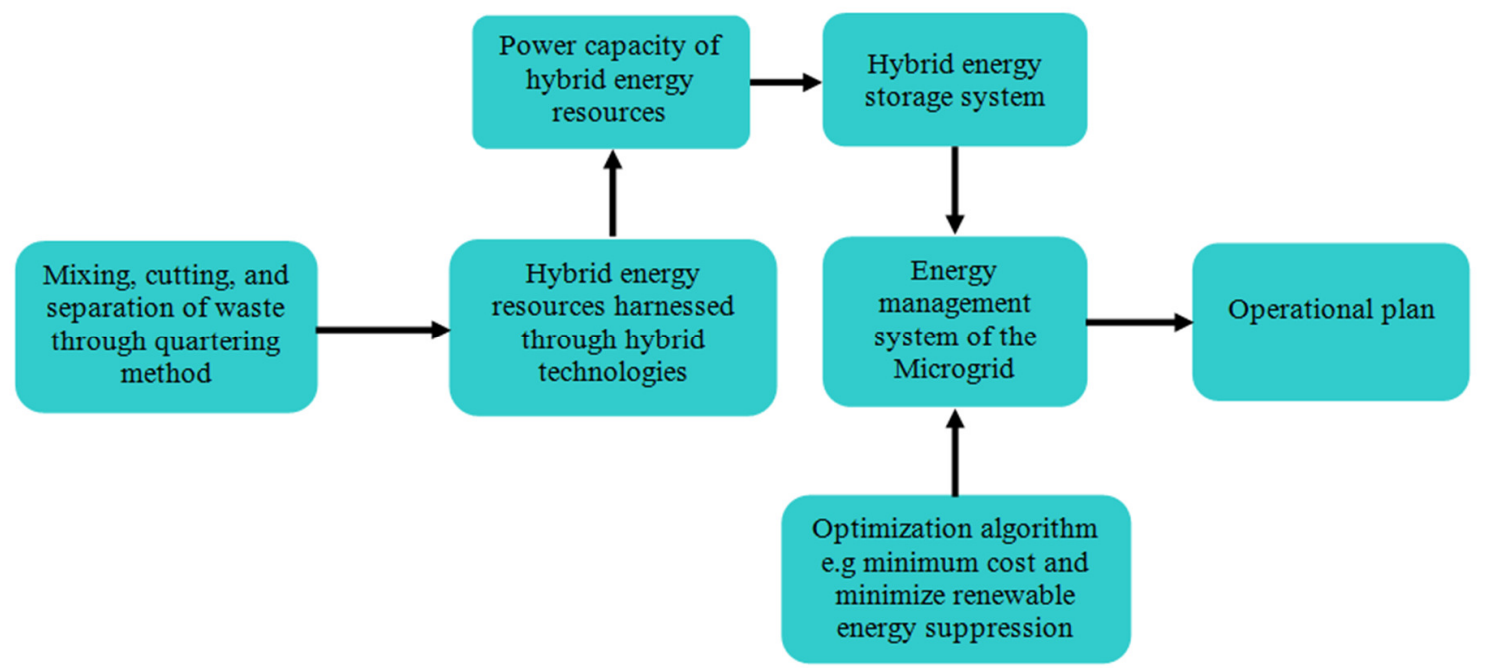

Fig. 4. Hybrid energy storage systems for renewable source integration in the microgrid energy management system.

\section{B. Power Generation Technology for Hybrid Resources}

The gasification technique for power generation is more suitable than the other techniques mentioned in Table III [2629]. The gasification technique accepts all types of waste (biomass and solid waste) for power generation with greater power production efficiency and has the capability of producing less ash. Gasification with its hybrid system opens the door for new development in the country because hybrid technologies based on other resources, including wind, solar, and nuclear, coupled with biomass and solid waste resources can provide more energy benefits to the community.

\section{Integration of Hybrid Biomass-Solid Waste Energy \\ Resources in a Microgrid}

Most renewable sources are used in microgrids with lower power levels (around $200 \mathrm{~kW}$ ) and are connected with the main bus through power converters [28-31]. These systems are installed near the commercial and industrial sites for meeting the power demand. These systems produce low noise and emissions which ultimately provide reliable power on low cost. The selection of a suitable renewable source is a complex process. This research paper has described a step-wise feasibility study of hybrid biomass and solid waste resource for microgrid development. Figure 4 shows the hybrid energy storage systems for hybrid renewable source (biomass/solid waste) integration in the energy management system of a microgrid. The integration of a hybrid energy storage system, distributed energy resources, and distributed loads with a renewable energy ecosystem is called microgrid. A microgrid helps to setup the smart and active electrical grid with the potential to increase the efficiency, reliability, and safety of the system.

\section{CONCLUSION}

This study aims to alleviate the current energy crisis and suggests future electricity pathways to drive the economy of a developing country such as Pakistan. An experiment was performed in the lab in order to identify the suitability for power generation of waste pallets collected from different sites of Pakistan. The results of this study were examined quantitatively to justify the feasibility of the energy plan. The projected power generation is $11,989.5 \mathrm{GW}$ which is sufficient to alleviate the ongoing energy crisis and facilitate the future industrial development in the country. Pakistan therefore needs to develop a new policy that is economically feasible and environmentally friendly for longer tenure. Hybrid energy resources provide a suitable option through hybrid technologies for microgrid development. 


\section{REFERENCES}

[1] S. Hansen, A. Mirkouei, and L. A. Diaz, "A comprehensive state-oftechnology review for upgrading bio-oil to renewable or blended hydrocarbon fuels," Renewable and Sustainable Energy Reviews, vol. 118, Feb. 2020, Art. no. 109548, https://doi.org/10.1016/j.rser.2019. 109548.

[2] F. Campuzano, R. C. Brown, and J. D. Martinez, "Auger reactors for pyrolysis of biomass and wastes," Renewable and Sustainable Energy Reviews, vol. 102, pp. 372-409, Mar. 2019, https://doi.org/10.1016/ j.rser.2018.12.014.

[3] O. K. M. Ouda, S. A. Raza, A. S. Nizami, M. Rehan, R. Al-Waked, and N. E. Korres, "Waste to energy potential: A case study of Saudi Arabia," Renewable and Sustainable Energy Reviews, vol. 61, pp. 328-340, Aug. 2016, https://doi.org/10.1016/j.rser.2016.04.005.

[4] W. Rulkens, "Sewage Sludge as a Biomass Resource for the Production of Energy: Overview and Assessment of the Various Options," Energy \& Fuels, vol. 22, no. 1, pp. 9-15, Jan. 2008, https://doi.org/10.1021/ ef700267m.

[5] A. R. K. Gollakota, N. Kishore, and S. Gu, "A review on hydrothermal liquefaction of biomass," Renewable and Sustainable Energy Reviews, vol. 81, pp. 1378-1392, Jan. 2018, https://doi.org/10.1016/j.rser. 2017.05.178.

[6] F. Manzano-Agugliaro, A. Alcayde, F. G. Montoya, A. Zapata-Sierra, and C. Gil, "Scientific production of renewable energies worldwide: An overview," Renewable and Sustainable Energy Reviews, vol. 18, pp. 134-143, Feb. 2013, https://doi.org/10.1016/j.rser.2012.10.020.

[7] K. L. Khatri, A. R. Muhammad, S. A. Soomro, N. A. Tunio, and M. M. Ali, "Investigation of possible solid waste power potential for distributed generation development to overcome the power crises of Karachi city," Renewable and Sustainable Energy Reviews, vol. 143, Jun. 2021, Art. no. 110882, https://doi.org/10.1016/j.rser.2021.110882.

[8] G. W. Huber, S. Iborra, and A. Corma, "Synthesis of Transportation Fuels from Biomass: Chemistry, Catalysts, and Engineering," Chemical Reviews, vol. 106, no. 9, pp. 4044-4098, Sep. 2006, https://doi.org/ $10.1021 / \mathrm{cr} 068360 \mathrm{~d}$.

[9] J. Ahrenfeldt, T. P. Thomsen, U. Henriksen, and L. R. Clausen, "Biomass gasification cogeneration - A review of state of the art technology and near future perspectives," Applied Thermal Engineering, vol. 50, no. 2, pp. 1407-1417, Feb. 2013, https://doi.org/10.1016/ j.applthermaleng.2011.12.040.

[10] G. Kumar et al., "A review of thermochemical conversion of microalgal biomass for biofuels: chemistry and processes," Green Chemistry, vol. 19, no. 1, pp. 44-67, 2017, https://doi.org/10.1039/C6GC01937D.

[11] M. Rehfeldt, E. Worrell, W. Eichhammer, and T. Fleiter, "A review of the emission reduction potential of fuel switch towards biomass and electricity in European basic materials industry until 2030," Renewable and Sustainable Energy Reviews, vol. 120, p. 109672, Mar. 2020, https://doi.org/10.1016/j.rser.2019.109672.

[12] M. Saghir, S. Zafar, A. Tahir, M. Ouadi, B. Siddique, and A. Hornung, "Unlocking the Potential of Biomass Energy in Pakistan," Frontiers in Energy Research, vol. 7, 2019, Art. no. 24, https://doi.org/10.3389/ fenrg.2019.00024.

[13] K. Kapadia and A. Agrawal, "Municipal Solid Waste to Energy Options - A Review," Social Science Research Network, Rochester, NY, SSRN Scholarly Paper ID 3361532, Mar. 2019. https://doi.org/10.2139/ssrn. 3361532.

[14] P. J. Verkerk et al., "Spatial distribution of the potential forest biomass availability in Europe," Forest Ecosystems, vol. 6, no. 1, Feb. 2019, Art. no. 5, https://doi.org/10.1186/s40663-019-0163-5.

[15] Z. Qin et al., "Biomass and biofuels in China: Toward bioenergy resource potentials and their impacts on the environment," Renewable and Sustainable Energy Reviews, vol. 82, pp. 2387-2400, Feb. 2018 , https://doi.org/10.1016/j.rser.2017.08.073.

[16] V. Ferreira-Leitao, L. M. F. Gottschalk, M. A. Ferrara, A. L. Nepomuceno, H. B. C. Molinari, and E. P. S. Bon, "Biomass Residues in Brazil: Availability and Potential Uses," Waste and Biomass Valorization, vol. 1, no. 1, pp. 65-76, Mar. 2010, https://doi.org/ 10.1007/s12649-010-9008-8.
[17] M. A. Wazir and A. Goujon, Assessing the 2017 Census of Pakistan Using Demographic Analysis: A Sub-National Perspective. Vienna, Austria: Vienna Institute of Demography, 2019.

[18] "GDP growth (annual \%)," The World Bank. https://data.worldbank.org/ indicator/NY.GDP.MKTP.KD.ZG (accessed May 26, 2021).

[19] SAARC Energy Outlook 2030. Mumbai, India: CRISIL, 2018.

[20] A. A. Yusuf and F. L. Inambao, "Effect of low bioethanol fraction on emissions, performance, and combustion behavior in a modernized electronic fuel injection engine," Biomass Conversion and Biorefinery, vol. 11, no. 3, pp. 885-893, Jun. 2021, https://doi.org/10.1007/s13399019-00519-w.

[21] A. Shehzad, M. J. K. Bashir, and S. Sethupathi, "System analysis for synthesis gas (syngas) production in Pakistan from municipal solid waste gasification using a circulating fluidized bed gasifier," Renewable and Sustainable Energy Reviews, vol. 60, pp. 1302-1311, Jul. 2016, https://doi.org/10.1016/j.rser.2016.03.042.

[22] Y. Yu et al., "Pyrolysis of Rice Husk and Corn Stalk in Auger Reactor. 1. Characterization of Char and Gas at Various Temperatures," Energy \& Fuels, vol. 30, no. 12, pp. 10568-10574, Dec. 2016, https://doi.org/ 10.1021/acs.energyfuels.6b02276.

[23] T. M. Ismail, A. Ramos, E. Monteiro, M. A. El-Salam, and A. Rouboa, "Parametric studies in the gasification agent and fluidization velocity during oxygen-enriched gasification of biomass in a pilot-scale fluidized bed: Experimental and numerical assessment," Renewable Energy, vol. 147, pp. 2429-2439, Mar. 2020, https://doi.org/10.1016/j.renene. 2019.10 .029 .

[24] C. Sheng and J. L. T. Azevedo, "Estimating the higher heating value of biomass fuels from basic analysis data," Biomass and Bioenergy, vol. 28, no. 5, pp. 499-507, May 2005, https://doi.org/10.1016/j.biombioe. 2004.11.008.

[25] (Draft) Guideline for Solid Waste Management. Islamabad, Pakistan: Pakistan Environmental Protection Agency, 2005.

[26] A. Gomez-Barea, P. Ollero, and B. Leckner, "Optimization of char and tar conversion in fluidized bed biomass gasifiers," Fuel, vol. 103, pp. 42-52, Jan. 2013, https://doi.org/10.1016/j.fuel.2011.04.042.

[27] S. H. Solangi, A. Q. Jakhrani, K. C. Mukwana, A. R. Jatoi, and M. R. Luhur, "Investigation of Quantity, Quality and Energy Content of Indigenous Sugarcane Trash in Naoshehro Feroze District, Sindh," Engineering, Technology \& Applied Science Research, vol. 8, no. 6, pp. 3609-3613, Dec. 2018, https://doi.org/10.48084/etasr.2411.

[28] K. Sookramoon, "80 kW Updraft Gasifier Performance Test using Biomass Residue Waste from Thailand Rural Areas," Engineering, Technology \& Applied Science Research, vol. 10, no. 5, pp. 6349-6355, Oct. 2020, https://doi.org/10.48084/etasr.3820.

[29] N. M. Kumar, S. S. Chopra, A. A. Chand, R. M. Elavarasan, and G. M. Shafiullah, "Hybrid Renewable Energy Microgrid for a Residential Community: A Techno-Economic and Environmental Perspective in the Context of the SDG7," Sustainability, vol. 12, no. 10, Jan. 2020, Art. no. 3944, https://doi.org/10.3390/su12103944.

[30] F. Aghaee, N. Mahdian Dehkordi, N. Bayati, and A. Hajizadeh, "Distributed Control Methods and Impact of Communication Failure in AC Microgrids: A Comparative Review," Electronics, vol. 8, no. 11, Nov. 2019, Art. no. 1265, https://doi.org/10.3390/electronics8111265.

[31] Bayati, N. Bayati, H. R. Baghaee, A. Hajizadeh, and M. Soltani, "Localized Protection of Radial DC Microgrids With High Penetration of Constant Power Loads," IEEE Systems Journal, pp. 1-12, 2020, https://doi.org/10.1109/JSYST.2020.2998059. 